\title{
Determinants of Financial Sustainability of Small Scale Sunflower Oil Processing Firms in Tanzania
}

\author{
Anastasia Njiku', Ganka Daniel Nyamsogoro ${ }^{2,}$, \\ ${ }^{1}$ Department of Accounting and Finance, University of Dodoma, Dodoma, Tanzania \\ ${ }^{2}$ Department of Accounting and Finance, Mzumbe University, Morogoro, Tanzania
}

Email address:

nyamso@gmail.com (G. D. Nyamsogoro)

${ }^{*}$ Corresponding author

\section{To cite this article:}

Anastasia Njiku1, Ganka Daniel Nyamsogoro. Determinants of Financial Sustainability of Small Scale Sunflower Oil Processing Firms in Tanzania. International Journal of Business and Economics Research. Vol. 8, No. 3, 2019, pp. 125-132. doi: 10.11648/j.ijber.20190803.16

Received: April 3, 2019; Accepted: May 31, 2019; Published: June 19, 2019

\begin{abstract}
Financial Sustainability of firms as a necessary condition for institutional permanence and long-lasting service has attracted scholarly attention in both developed and developing world over several decades. Little attention however, has been paid to small scale agro-processing firms' context in developing economies like Tanzania. This study was set to investigate factors influencing financial sustainability of small scale sunflower oil processing firms in Tanzania. The study used 219 small scale sunflower oil processing firms randomly selected in central sunflower agricultural corridor of Dodoma and Singida regions in Tanzania. Data collected were analyzed by using Hieratical Multiple Linear Regression model, where a number of firm specific factors were considered as important determinants of financial sustainability while controlling for differences in technical efficiency levels. It was found that location of the firm, age of the owner and training of the employees are statistically significantly influencing financial sustainability in sunflower oil processing firms in Tanzania. In addition, technical efficiency contributes significantly on financial sustainability of small scale sunflower oil processing firms (SSSOPF). The findings imply the need for the government and other agencies in the sector to nurture entrepreneurial aspirations in tender age and consider clustering firms in the designed industrial areas for easy accessibility of inputs and support services. Moreover, improving technical efficiency is a pre-requisite for financial sustainability of SSSOPF in Tanzania.
\end{abstract}

Keywords: Determinants, Financial Sustainability, Small-Scale Sunflower Oil Processing

\section{Introduction and Background}

Sunflower is one of the potential cash crops in Tanzania introduced since colonial times from America and Europe and found to grow in almost all parts of the country [1]. The crop is very interesting as it grows well in dry weather conditions particularly in the Central Agricultural Corridor of Singida and Dodoma regions. It is very important crop grown by pro-poor small holder farmers as a means of reducing poverty through employment creation and income generation due to limited public employment opportunities in public sectors.

Despite of the predominance of sunflower oil processing firms in central agricultural corridor of Dodoma and Singida regions due to availability of sunflower seeds, mostly are of small scale unable to grow as expected with low standard produce to meet for international markets hence low profitability [2]. As a result, three (3) out of five (5) firms fail within their few months of their establishment [3]. This raise uncertainty on their ability to meet their operating and financing expenses from their income generated.

Moreover, there are limited empirical evidences on the determinants of financial sustainability for processing firms, particularly on sunflower oil processing sub-sector in Tanzania context. Most of the previous studies on the financial sustainability in Tanzania focused on the Microfinance Institutions [4-6]. Though they provided a good background on the established relationship, but the solutions that worked elsewhere might not be applicable on different sectors due to contextual and methodological differences. For instance, the study by Nyamsogoro on the financial 
sustainability of Rural Microfinance Institutions used Panel Regression and found that capital structure, firm size, staff productivity and operating efficiency affect the financial sustainability of the firms under the study[6]. On the other hand, the study suggested that geographical location can be a proxy for some differences in performance. This study takes it further and investigates whether location of SSSOPF can influence its financial sustainability. Likewise, the study by Kipesha and Zhang on efficiency, financial sustainability and profitability of Microfinance institution in East Africa revealed that firm characteristics, particularly age and size influence the sustainability of the firm [4]. However, due to differences in institutional background and operations the generalizabity of the findings to other different sectors is questionable.

This study is grounded from the microfinance settings, particularly the study by Kipesha and Zhang, Marwa and Aziakpono, and Nyamsogoro [4-6]. These studies established the relationship between various firms specific factors like firm age, size, ownership of the firm, education level and the age of the owner and efficiency of the firms respectively as the determinants of financial sustainability in Microfinance empirical setting other than sunflower oil processing firms which is the focus of this study.

The findings of this study are important to various stakeholders like government and private agencies responsible for creating enabling environments for small scale's firm financial sustainability, policy makers, ownermanagers and researchers. Specifically, the findings of the study provide input information to policy makers on various interventions and devising specific policy as a means toward improving the financial sustainability for sunflower oil processing firms in Tanzania. The study is also beneficial to the owner-managers of the firms as it provides an understanding of important variables like location, age and technical efficiency levels in predicting the financial sustainability of their firms. Moreover, the study adds to the limited stock of literature on the determinants of financial sustainability, with specific reference to sunflower oil processing firms in Tanzania.

\section{Literature Review}

\subsection{The Concept of Financial Sustainability}

Theoretically, sustainability is a wide term and has been defined by many in several dimensions depending on user requirements. For instance, Filene defined sustainability as the ability of an entity to continue a defined behavior indefinitely [7]. It further implies the ability of the firm to meet its goals over the long term. In the same vein, Nyamsogoro in the Microfinance sector defined sustainability to mean permanence or the ability to repeat performance through time [6]. Other scholars in a business sector like Hubbard described sustainability as the ability of the firm to meet the need of its stakeholders without compromising its ability to meet their needs in the future [8].
In other words, financial sustainability means the smooth operation of the firm with the necessary profitability, having adequate liquidity to overcome any challenges of bankruptcy. It is also considered as a necessary condition for institutional sustainability which is the most important requirement for any business. According to Doicui financial sustainability is a full cost recovery or profit making and is associated with the aim of building an institution that can last into the future without continual reliance on government subsidies or donor funds [9]. It is the ability of an institution to meet its operational costs from income generated from services or products provided and have enough reserves for recapitalization [10]. In this study, the financial sustainability refers to the ability of sunflower oil processing firm to survive in the business and be able to meet its operational and financing expenses from its income generated thus has enough profit for recapitalization in a long run. Specifically, it is the ability of a sunflower oil processing firms to generate income that exceeds its total costs hence survival in business for long time. Profitability is therefore considered as a residual and a proxy measure the firm financial sustainability.

\subsection{Measures of Financial Sustainability}

Previous literature encored the measurements of financial sustainability in two levels of indicators Operational SelfSufficiency (OSS) and Financial Self-Ssufficiency (FSS) [46]. Operational Self-Sufficiency has been used to assess how far an institution has come in covering its operating expenses with its operating income regardless of the source while financial self-sufficiency measures the extent to which operating revenue can cover institution's direct and indirect costs from its income generation [10]. Moreover, Financial Self-Sufficiency is considered to be more appropriate measure of sustainability as it attempts to show the financial picture of the firm on unsubsidized basis $[6,10]$. It is defined as the ratio of adjusted financial revenue to total expenses. The ratio above 1 indicates sustainability while below 1 indicates the incapability of the firm to pay all of their expenses from their own generated income and therefore not financially sustainable.

$$
F S S=\frac{\text { Adusted Financial Revenue }}{\text { Adjusted Operating Expenses }}
$$

In this study, Financial Self- sufficiency (FSS) has been adopted as a measure of the sunflower oil processing firm financial sustainability as ratio of total expenses to total revenue. This is due to their nature of being small scale firms constrained with collateral challenges in acquiring loans and thus use internally generated fund as a main source of capital. Additionally, sunflower oil processing firms sell their products on cash basis due to their open market nature of the business and thus no any accruals to be adjusted for.

Also from the profitability theory point of view, profit is considered as the residual, calculated as an excess of income over expenditure to mean financial sustainability $[11,6]$. In other words, Marriott et al considered profits as what remain 
after costs of productions have been paid for[12]. If profit is considered as a residual, then profitability can be used as a proxy measure of financial sustainability since it considers covering all costs incurred in earning plus any costs necessary to at least maintain the current level of operations [12].

Moreover, the profit of the firm can be increased by either increasing income while holding expenses constant, or by holding income constant and reducing expenses or both. It comes therefore, that determinants of income and expenses are equally the determinants of the profit [10]. All things being equal profits have been considered to be a key variable in measuring a firm's financial sustainability.

\subsection{The Concept of Technical Efficiency}

Efficiency refers to reaching the desired output with the minimum input or means [10]. It is the relationship between inputs and output that seeks to minimize resources costs. The conception of Technical efficiency is centered on inputoutput relationship. Technical efficiency is achieved when a minimum possible input is used to produce a given level of output or when a maximum possible output is produced given a certain level of input [13-19]. In this study, technical efficiency was used as a measure of the effectiveness of transformation of a set of inputs resources given and technology into maximum outputs [20]. It was computed from capital, labour and material costs as inputs originally measured in Tshs as well as unit processed in liters as output but were all transformed into their natural logs. Each firm specific technical efficiency scores were computed as continuous variable for inclusion in the regression analysis [20].

\subsection{Determinants of Financial Sustainability}

This study was based on factors documented in previous studies as influencing financial Sustainability of firms. These factors from different study settings and firm orientation were used in this study in investigating the factors that could affect financial sustainability of SSSOPF. These include: location of the business; number of employees as a measure of firm size; education level of the owner; ownership type [6], number of years in operations as a measure of firm age $[6,21]$, training of employees [22], age [6, 23] experience [24], and efficiency [5-6]. All withstanding however, the available empirical work is limited to Microfinance Institutions which plays a great role in providing capital to the small scale firms thus regarded as the supply side. Though these empirical evidences have provided a good background on the established relationship among the variables, they reported mixed evidences on the influence of firm specific factors and performance, not only in the Microfinance industry but also in other industries like manufacturing as well. The mixed evidences suggest that the relationship between firm specific factors with performance is not linear. Thus, make generalization of the findings across sectors and sub-sectors questionable.
Therefore, our empirical evidence is confined to sunflower oil processing firms themselves from what they possess internally (the demand side point of view), as on the extent to which firm specific characteristics determine their financial sustainability. It focused on firm specific characteristics, which play a crucial role in explaining their performance since they are within the control of the firm. Also following the resource based theory; we consider the firm specific factors as bundles of resources which are combined in a best way to create organizational capabilities for superior performance [25]. That is, firm size, age, location, ownership type, education level, age and experience of the ownermanager, training of the employees and technical efficiency are considered as resources and capabilities which can be combined in explaining the financial sustainability of sunflower oil processing firms in Tanzania.

\section{Methodology}

This study used quantitative approach to determine significant firm specific factors influencing financial sustainability of sunflower oil processing firms in Tanzania. The study covered 219 firms located in Dodoma and Singida regions. The data used and model specifications are presented in the next sections.

\subsection{The Data}

A set of primary cross-sectional firm - level data was collected from for 219 sunflower oil processing firms in Dodoma and Singida regions using both questionnaires and interviews. Dodoma and Singida regions were purposely selected as central agricultural corridor and processing potential of sunflower oil in Tanzania. The highest produced amount of sunflower seeds in this area has led to predominance of sunflower oil processing industries along Dar-es salaam to lake zones and Arusha highways.

The owners of the firms were purposely selected and interviewed as primary sources on important data particularly on the quantity produced on liters, price per liter, quantity of raw materials used and the price per bag, average daily wages for labour, other operating expenses incurred daily and the number of personnel in their respective firms. The study used simple random sampling technique in selecting sunflower oil processing firms in the area where only owners were purposively selected as targeted respondents. This was due to the fact that sunflower oil processing firms are of small- scale in nature mainly owned and controlled by individuals.

\subsection{Model Specification}

Hierarchical Multiple Linear Regression (HMR) technique was used to analyze the determinants of financial sustainability of sunflower oil processing firms in Tanzania. This regression technique was considered necessary given its ability to effectively capture cause-effect relationship while holding the differences in Technical Efficiency levels 
constant. In addition, the data had a continuous dependent variable with continuous and categorical independent variables, which made multiple linear regression models suitable for this study. In this model, a dependent variable is modeled as a function of several independent variables with corresponding coefficients along with the constant term. The general operational equation of linear regression is given by:

$$
E(Y)_{i}=\alpha+\beta_{i} X_{i}+\cdots+\beta_{n} X_{n}
$$

Where, $E\left(Y_{i}\right)$ is the mean of the response variable, $X_{i}$ are independent variables, and $\beta_{i}$ are their respective parameters. Independent variables used in this study are: location of the business; firm size measured in number of employees; education level; ownership type; firm age; training of employees as measure by a dummy variable; age of owner; experience of owner; and technical efficiency measured by efficiency scores for each firm.

According to Field, $R$ square $\left(\mathrm{R}^{2}\right)$ which is the coefficient of multiple determinations is one of the useful statistics used to examine the amount of variance explained in the outcome variable by the predictors in the model [26]. Importantly, in applying Hierarchical Multiple Linear Regression model, some groundwork analyses were performed to ensure that no violation of the assumptions of multiple linear regressions for valid and reliable results. Regression diagnostic tests were conducted. These are: linear relationship between (a) the dependent variable and each of the independent variables, and (b) the dependent variable and the independent variables collectively. The independence of observations (residuals), homoscedasticity of data, checking of multicollinearity problem, and finally the normally distribution of the residuals. Regression diagnostic tests did not reveal any problem that might affect reliability of the regression model.

Technical efficiency measures the effectiveness transformation of inputs into maximum outputs thus provides more comprehensive measure of the firm efficiency. Additionally, efficiency influence financial sustainability of the firm through cost reduction or revenue increase or both [6]. In this study, technical efficiency scores were used as proxy measure of firm's efficiency. The scores were estimated for each firm as continuous variables using a stochastic production frontier as indicated on table 1 of variable description.

Table 1. Variable Descriptions and Measurements.

\begin{tabular}{|c|c|c|c|c|c|}
\hline $\mathbf{S} / \mathbf{N}$ & Variable & Definition and Measurement & $\begin{array}{l}\text { Expected } \\
\text { sign on FS }\end{array}$ & Comments & $\begin{array}{l}\text { Reference (where } \\
\text { applicable) }\end{array}$ \\
\hline 1 & Firm Size & $\begin{array}{l}\text { Continuous variable measured by the number of } \\
\text { employees in each firm. }\end{array}$ & - & $\begin{array}{l}\text { Large number of employees increases } \\
\text { costs thus reduces profit }\end{array}$ & {$[13,27-29]$} \\
\hline 2 & Firm age & $\begin{array}{l}\text { Continuous variable in number of years of the } \\
\text { firm in operation since establishment }\end{array}$ & + & $\begin{array}{l}\text { Old age means more experiences } \\
\text { through learning by doing, thus } \\
\text { improve performance }\end{array}$ & {$[22,28,30,31]$} \\
\hline 3 & Firm location & $\begin{array}{l}\text { Dummy variable that was assigned numbers } \\
\text { according to regions. } \\
1 \text { for Singida and } 0 \text { for Dodoma }\end{array}$ & + & $\begin{array}{l}\text { Urban/township areas are strategic } \\
\text { located for easy accessibility of various } \\
\text { opportunities }\end{array}$ & {$[13,27,29,30]$} \\
\hline 4 & Ownership type & $\begin{array}{l}\text { Dummy variable measured as types of business } \\
\text { ownership } 1 \text { sole proprietor and } 0 \text { partnership }\end{array}$ & + & $\begin{array}{l}\text { legal structure of the firm enhance } \\
\text { profitability, }\end{array}$ & {$[27-28,30-31]$} \\
\hline 5 & $\begin{array}{l}\text { Training of } \\
\text { employees }\end{array}$ & $\begin{array}{l}\text { Dummy variable measured as } 1 \text { for trained and } 0 \\
\text { for untrained }\end{array}$ & + & $\begin{array}{l}\text { Relevant training enhance financial } \\
\text { sustainability }\end{array}$ & {$[22,32]$} \\
\hline 6 & $\begin{array}{l}\text { Industrial experience } \\
\text { of the owner }\end{array}$ & $\begin{array}{l}\text { Continuous variable in number of years of } \\
\text { accumulated industrial experience }\end{array}$ & + & $\begin{array}{l}\text { Accumulated working experience } \\
\text { enhance profitability }\end{array}$ & {$[13,27]$} \\
\hline 7 & $\begin{array}{l}\text { Education of the } \\
\text { owner }\end{array}$ & $\begin{array}{l}\text { Categorical variable measured by the } \\
\text { qualification levels of education of the owner }\end{array}$ & + & $\begin{array}{l}\text { High education level means more } \\
\text { knowledge and skills for improved } \\
\text { performance }\end{array}$ & {$[22,30]$} \\
\hline 8 & Age of the owner & Continuous variable, measured in years. & + & $\begin{array}{l}\text { increase in age means increasing in } \\
\text { experience and so increases profit }\end{array}$ & {$[5,29,30]$} \\
\hline 9 & $\begin{array}{l}\text { Technical Efficiency } \\
\text { scores }\end{array}$ & $\begin{array}{l}\text { Continuous variable estimated from a ratio of } \\
\text { output to input factors of production for each firm }\end{array}$ & + & $\begin{array}{l}\text { Maximum output increases the profit } \\
\text { hence financial sustainability }\end{array}$ & {$[4-6,20]$} \\
\hline 10 & $\begin{array}{l}\text { Financial Self } \\
\text { Sufficient (FSS) }\end{array}$ & $\begin{array}{l}\text { Continuous variable and a measure of Financial } \\
\text { Sustainability as the ratio of Revenue/expenses. }\end{array}$ & $\begin{array}{l}\text { (depended } \\
\text { variable) }\end{array}$ & $\begin{array}{l}\text { Ratio }>1 \text { means Financially sustainable } \\
\text { Ratio }<1 \text { means not sustainable. }\end{array}$ & {$[5-6]$} \\
\hline
\end{tabular}

\section{Results and Discussion}

This study aimed to determine the influence of firm specific factors taking into account technical efficiency scores differences on financial sustainability for sunflower oil processing firms in Tanzania. Previous studies did not use technical efficiency scores as control variables when assessing the influence of firm specific factors on financial sustainability, thus its contribution is scantly found. This paper therefore fills this knowledge gap by using Hierarchical Multiple Linear Regression where two blocks of variables were fitted in two different models for firm specific factors and technical efficiency scores respectively.

\subsection{Descriptive Statistics}

The descriptive statistics explaining the overall distribution of the variables included in the model as presented in Table 2. 
Table 2. Descriptive Statistics.

\begin{tabular}{|c|c|c|c|c|c|}
\hline \multirow{2}{*}{ Variables } & $\mathbf{N}$ & Minimum & Maximum & Mean & Std. Deviation \\
\hline & Statistic & Statistic & Statistic & Statistic & Statistic \\
\hline Location of the business & 219 & 0 & 1 & .61 & .489 \\
\hline Firm size & 219 & 5 & 28 & 8.54 & 4.437 \\
\hline Ownership type & 219 & 0 & 1 & .69 & .464 \\
\hline Firm age & 219 & 3 & 12 & 4.99 & 1.955 \\
\hline Education of the owner & 219 & 1 & 4 & 1.63 & .811 \\
\hline Training of the employees & 219 & 0 & 1 & .68 & .469 \\
\hline Experience of the owner & 219 & 1 & 10 & 4.34 & 2.040 \\
\hline Technical Efficiency levels & 219 & .03 & .79 & .5286 & .14874 \\
\hline Financial self Sufficiency & 219 & .04 & 1.10 & .9410 & .15515 \\
\hline
\end{tabular}

The results in Table 2 indicate that on average, sunflower oil processing firms under the study are not financially selfsufficient as their overall mean ratio is below $1(0.94)$. This implies that most of sunflower oil processing firms are not able to cover their operating expenses from internally generated income, though they are nearly break evening (retaining their operating capital). Thus any improvement on the significant variables would mean profitability and hence financial sustainability of the firms. Likewise, the results in Table 2 depicts that on average sunflower oil processing firms operate at a mean technical efficiency level of 53\% implying that there is an opportunity for more improvement by $47 \%$ under a better use of inputs and technology.

However, most of the sunflower oil processing firms had 9 employees which have been used as a proxy measure of firm size. This observation justify that, sunflower oil processing firms are of small scale in nature since their number of employees ranges from 5 to 28 but majority do have around 9 employees. Also in average mostly have been in operation for five years since their establishment.

Likewise, it has been revealed that the owners of sunflower oil processing firms are youth and middle aged of around 41 years with an average of four years of industrial working experience. On average, age of the owner reflects the fact that most of the respondents are mature, motivated and energetic whose economic reality and the survival instinct must have driven into the establishment of the businesses. Importantly, a pair wise correlation among the variables fitted in the model was tested to ensure that the variables are not correlated. The results in Table 3 revealed that the variables are not

correlated and thus included in the model of analysis.

Table 3. Pair wise correlation matrix.

\begin{tabular}{|c|c|c|c|c|c|c|c|c|c|}
\hline Variable & $\begin{array}{l}\text { Pearson } \\
\text { Correlation } \\
\end{array}$ & Location & Firm size & Firm age & Education & Age of the owner & Experience & $\begin{array}{l}\text { TE } \\
\text { Scores }\end{array}$ & FSS \\
\hline Location & $\begin{array}{l}\text { Pearson Correlation } \\
\text { Sig. (2-tailed) }\end{array}$ & 1 & & & & & & & \\
\hline Firm size & $\begin{array}{l}\text { Pearson Correlation } \\
\text { Sig. (2-tailed) }\end{array}$ & $\begin{array}{l}-.004 \\
.959\end{array}$ & 1 & & & & & & \\
\hline Firm age & $\begin{array}{l}\text { Pearson Correlation } \\
\text { Sig. (2-tailed) }\end{array}$ & $\begin{array}{l}.023 \\
.734\end{array}$ & $\begin{array}{l}.072 \\
.287\end{array}$ & 1 & & & & & \\
\hline $\begin{array}{l}\text { Education } \\
\text { level of the } \\
\text { owner }\end{array}$ & $\begin{array}{l}\text { Pearson Correlation } \\
\text { Sig. (2-tailed) }\end{array}$ & $\begin{array}{l}.055 \\
.414\end{array}$ & $\begin{array}{l}-.056 \\
.411\end{array}$ & $\begin{array}{l}.066 \\
.329\end{array}$ & 1 & & & & \\
\hline $\begin{array}{l}\text { Age of the } \\
\text { owner }\end{array}$ & $\begin{array}{l}\text { Pearson Correlation } \\
\text { Sig. (2-tailed) }\end{array}$ & $\begin{array}{l}.038 \\
.572\end{array}$ & $\begin{array}{l}-.032 \\
.637\end{array}$ & $\begin{array}{l}.190^{* *} \\
.005\end{array}$ & $\begin{array}{l}.066 \\
.331\end{array}$ & 1 & & & \\
\hline $\begin{array}{l}\text { Experience of } \\
\text { the owner }\end{array}$ & $\begin{array}{l}\text { Pearson Correlation } \\
\text { Sig. (2-tailed) }\end{array}$ & $\begin{array}{l}-.172^{*} \\
.011\end{array}$ & $\begin{array}{l}-.051 \\
.454\end{array}$ & $\begin{array}{l}-.046 \\
.498\end{array}$ & $\begin{array}{l}.006 \\
.932\end{array}$ & $\begin{array}{l}.083 \\
.219\end{array}$ & 1 & & \\
\hline TE Scores & $\begin{array}{l}\text { Pearson Correlation } \\
\text { Sig. (2-tailed) }\end{array}$ & $\begin{array}{l}.094 \\
.165\end{array}$ & $\begin{array}{l}.104 \\
.125\end{array}$ & $\begin{array}{l}-.006 \\
.935\end{array}$ & $\begin{array}{l}-.046 \\
.495\end{array}$ & $\begin{array}{l}-.105 \\
.121\end{array}$ & $\begin{array}{l}-.075 \\
.267\end{array}$ & 1 & \\
\hline FSS & $\begin{array}{l}\text { Pearson Correlation } \\
\text { Sig. (2-tailed) }\end{array}$ & $\begin{array}{l}.171^{*} \\
.011\end{array}$ & $\begin{array}{l}.036 \\
.592\end{array}$ & $\begin{array}{l}.005 \\
.936\end{array}$ & $\begin{array}{l}-.046 \\
.500\end{array}$ & $\begin{array}{l}-.152^{*} \\
.025\end{array}$ & $\begin{array}{l}-.137^{*} \\
.042\end{array}$ & $\begin{array}{l}.857^{* *} \\
.000\end{array}$ & 1 \\
\hline
\end{tabular}

Results in Table 3 indicate that correlation coefficients among the variables was less than 0.7 except for Financial Self Sufficiency (FSS) and Technical Efficiency scores (TE) which was 0.857 (greater than 0.7 ), but this was of no harm to the results since the Variance Inflation Factor (VIF) between these variable is 1.049 less than the recommended value of
10 to imply non-existence of multicollliearity problems among the variables as shown on table 6 of regression coefficient and thus guaranteed the analysis. Also, the tolerance values obtained were all higher than the cutoff point of 0.1 below which the multicollinearity could have been considered to be a problem [33]. 


\subsection{Determinants of Financial Sustainability}

A hierarchical Multiple Linear regression model was used to determine the influence of firm specific variables and technical efficiency scores as key variables in predicting the financial sustainability of sunflower oil processing firms in
Tanzania. The results obtained from a regression model has two models listed in Model Summary from which Model 1 refers to the first block of variables, firm specific factors that were entered while Model 2 includes all the variables, the firm specific factors and the technical efficiency scores which were entered in both blocks as follows.

Table 4. Model Summary ${ }^{\mathrm{C}}$.

\begin{tabular}{|c|c|c|c|c|c|c|c|c|c|c|}
\hline \multirow{2}{*}{ Model } & \multirow{2}{*}{$\mathbf{R}$} & \multirow{2}{*}{$\begin{array}{l}\text { R } \\
\text { Square }\end{array}$} & \multirow{2}{*}{$\begin{array}{l}\text { Adjusted } \\
\text { R Square }\end{array}$} & \multirow{2}{*}{$\begin{array}{l}\text { Std. Error of } \\
\text { the Estimate }\end{array}$} & \multicolumn{5}{|l|}{ Change Statistics } & \multirow{2}{*}{$\begin{array}{l}\text { Durbin- } \\
\text { Watson }\end{array}$} \\
\hline & & & & & R Square Change & F Change & df1 & df2 & Sig. F Change & \\
\hline 1 & $.304^{\mathrm{a}}$ & .092 & .058 & .15059 & .092 & 2.675 & 8 & 210 & .008 & \\
\hline 2 & $.871^{\mathrm{b}}$ & .758 & .748 & .07789 & .666 & 575.905 & 1 & 209 & .000 & 1.804 \\
\hline
\end{tabular}

a Predictors: (Constant), Industrial Experience of the owner, Education level of the owner, firm size, Age of the owner, Ownership type, Location of the firm, firm age, Training of the employees.

${ }^{\mathbf{b}}$ Predictors: (Constant), Industrial Experience of the owner, Education level of the owner, firm size, Age of the owner, Ownership type, Location of the firm, firm age, Training of the employees and Technical Efficiency levels.

c. Dependent Variable: Financial Self Sufficiency

Table 4 indicate that Model 1 summary results revealed that firm specific factors predict the financial statement of the firm by only $9.2 \%$ variance after the firm specific variables in Block 1 have been entered. The small $\mathrm{R}$ Square value in block one implies that, financial sustainability could be explained by other factors apart from location of the firm, size, age, education level, age of the owner, training of the employees and ownership type. Thus, technical efficiency levels (scores) were deemed important for inclusion in block two. After Block 2 variable-technical efficiency scores have been included in the model, the R Square raised to $75.8 \%$. R Square change was used to find out how much of this overall variance is explained by technical efficiency scores variables as a control variable and was found to explain by $66.6 \%$ (R Square Change) an additional of the variance in explaining the financial sustainability. Also, the ANOVA Table 5 indicates that the contribution of technical efficiency to the Financial Sustainability is a statistically significant by the significant $\mathrm{F}$ change value of $\left(000^{\mathrm{c}}\right)$.

Additionally, the ANOVA Table shows that the model as a whole including both blocks of variables is statistically significant $[\mathrm{F}(9,209)=72.876, \mathrm{p}<0.0005)$. This imply that technical efficiency is important condition/stepping stone toward the financial sustainability of the firm.

Table 5. $A N O V A^{a}$.

\begin{tabular}{llllll}
\hline Model & & Sum of Squares & df & Mean Square & Fig. \\
\cline { 2 - 6 } & Regression & .485 & 8 & .061 & 2.675 \\
& Residual & 4.762 & 210 & .023 & $.008 \mathrm{~b}$ \\
& Total & 5.248 & 218 & & \\
& Regression & 3.980 & 9 & .442 & $.000 \mathrm{c}$ \\
& Residual & 1.268 & 209 & .006 & \\
& Total & 5.248 & 218 & & \\
\hline
\end{tabular}

a. Dependent Variable: Financial self Sufficiency.

b. Predictors: (Constant), Experience of the owner, Education level of the owner, firm size, Age of the owner, Ownership type, Location of the firm, firm age and Training of the employees.

c. Predictors: (Constant), Experience of the owner, Education level of the owner, firm size, Age of the owner, Ownership type, Location of the firm, firm age, Training of the employees and Technical Efficiency levels.

Furthermore, the regression Coefficient Table 6 indicates significant variables influencing financial sustainability for sunflower oil processing firms in Tanzania.

Table 6. Regression Coefficients on Determinants of Financial Sustainability.

\begin{tabular}{|c|c|c|c|c|c|c|c|}
\hline \multirow[t]{2}{*}{ Model } & \multicolumn{2}{|c|}{ Unstandardized Coefficients } & \multirow{2}{*}{$\begin{array}{l}\text { Standardized Coefficients } \\
\text { Beta }\end{array}$} & \multirow[t]{2}{*}{$\mathbf{t}$} & \multirow[t]{2}{*}{ Sig. } & \multicolumn{2}{|c|}{ Collinerity Statistics } \\
\hline & B & Std. Error & & & & Tolerance & VIF \\
\hline \multicolumn{8}{|l|}{ Model 1} \\
\hline Constant & .986 & .069 & & 14.229 & $.000 * *$ & & \\
\hline Location of the firm & .056 & .021 & .177 & 2.629 & $.009 * *$ & .957 & 1.045 \\
\hline Firm size & .001 & .002 & .030 & .447 & .655 & .984 & 1.016 \\
\hline Firm age & .001 & .005 & .014 & .212 & .832 & .929 & 1.077 \\
\hline Ownership type & .025 & .023 & .074 & 1.097 & .274 & .952 & 1.051 \\
\hline Training of employees & .050 & .023 & .150 & 2.177 & $.031 * *$ & .914 & 1.094 \\
\hline Age of the owner & -.002 & .001 & -.128 & -1.875 & .062 & .929 & 1.077 \\
\hline
\end{tabular}




\begin{tabular}{|c|c|c|c|c|c|c|c|}
\hline \multirow[t]{2}{*}{ Model } & \multicolumn{2}{|c|}{ Unstandardized Coefficients } & \multirow{2}{*}{$\begin{array}{l}\text { Standardized Coefficients } \\
\text { Beta }\end{array}$} & \multirow[t]{2}{*}{$\mathbf{t}$} & \multirow[t]{2}{*}{ Sig. } & \multicolumn{2}{|c|}{ Collinerity Statistics } \\
\hline & B & Std. Error & & & & Tolerance & VIF \\
\hline \multicolumn{8}{|l|}{ Model 1} \\
\hline Experience of owner & -.005 & .005 & -.067 & -.982 & .327 & .926 & 1.080 \\
\hline (Constant) & .517 & .041 & & 12.643 & $.000^{* *}$ & & \\
\hline \multicolumn{8}{|l|}{ Model 2} \\
\hline Location of the firm & .029 & .011 & .091 & 2.614 & $.010^{* *}$ & .947 & 1.056 \\
\hline Firm Size & -.002 & .001 & -.055 & -1.599 & .111 & .974 & 1.027 \\
\hline Firm age & .001 & .003 & .016 & .450 & .653 & .929 & 1.077 \\
\hline Ownership type & .015 & .012 & .045 & 1.292 & .198 & .951 & 1.052 \\
\hline Education of the owner & -.006 & .007 & -.030 & -.839 & .402 & .926 & 1.080 \\
\hline Training of employees & .020 & .012 & .059 & 1.657 & .099 & .904 & 1.107 \\
\hline Age of the owner & -.006 & .001 & -.164 & -4.444 & $.000^{* *}$ & .922 & 1.084 \\
\hline Experience of owner & -.003 & .003 & -.045 & -1.277 & .203 & .925 & 1.081 \\
\hline Technical Eff. levels & .872 & .036 & .836 & 23.998 & $.000 * *$ & .954 & 1.049 \\
\hline
\end{tabular}

** Significant at 5\% level.

Table 6 indicates that independent variables in both models jointly predict the financial sustainability of sunflower oil processing firms positively and statistically significantly with a constant beta $\left(\beta_{0}\right)$ coefficient of 0.986 for model 1 and 0.517 for model 2 respectively.

Also before technical efficiency level differences were taking into account in model I only location of the firm and training of the employees appeared to influence financial sustainability of sunflower oil processing firms positively and statistically significant at beta coefficient of $(\beta=0.056$, $\mathrm{p}=.009)$ for location and $(\beta=0.050, \mathrm{p}=.031)$ for training of employees. This implies the need to locate business strategically. It also calls for the need to emphasis on training of employees. All withstanding however, independent variables can explain variations in the dependent variable by only $5.8 \%$ (adjusted R. squared). This implies, there are other important firm specific variables which influence financial sustainability.

On the other hand, when technical efficiency scores are introduced in Model 2, the Adjusted R Square raises to $75.8 \%$ implying that technical efficiency is an important predictor of the financial sustainability in sunflower oil processing firms with positive and highly statistical significant beta coefficient of $(\beta=0.872, p=0.000)$. That is, improvement in technical efficiency increases financial sustainability.

Moreover, taking into account technical efficiency differences, age of the owner also became significant determinants of financial sustainability which was not the case in model one. It is negatively related to financial sustainability to mean that financial sustainability of sunflower oil processing firm decreases with age of the owner. This is evident only when technical efficiency scores are introduced in the model, which implies that efficiency decreases with age and despite the experience gained, negatively affects financial sustainability. The less importance of experience where there is no efficiency is also seen in low values of beta coefficients. Age of owner also becomes significant as now it is being associated with decreasing efficiency. Thus, despite of their accumulated experience owners through learning by doing the performance declines with age. This is different from other subsectors due to the nature of the industry as it requires high mobility from material seeking, production and packaging of the products. The findings are in line with the study by Lévesque and Minniti which pointed out those younger business owners run businesses that perform better than old ones, since they are more motivated, energetic, committed and are less risk averse [21]. This has also been supported by Belenzon and Zarutskie that performance of the firm drops as the owner grows older [23].

\section{Conclusions and Implication of the Findings}

This study examined the determinants of financial sustainability of small scale sunflower oil processing firms in Tanzania. It was revealed that location of the firm, age of the owner and training of the employees are significant determinants of financial sustainability of sunflower oil processing firms in Tanzania. Moreover, technical efficiency matters a lot in determining financial sustainability of sunflower oil processing firms. The findings imply the need for the government and other agencies in the sector to nurture entrepreneurial aspirations in tender age and consider clustering firms in the designed industrial areas for easy accessibility of inputs and support services. Moreover, improving technical efficiency is a pre-requisite for financial sustainability.

\section{References}

[1] Rural Livelihood Development Company (RLDC) (2008). Sunflower Sector; Market Development Strategy, an initiative by Rural Livelihood Development Company. [Online]: http//www.rldc.co.tz/docs/sunflower.pdf.

[2] Mpeta, D. F. (2015). Effects of Contract Farming on production and Income of Sunflower Farmers in Kongwa District in Central Agricultural Zone of Tanzania. PhD Thesis, Mzumbe University, Morogoro, Tanzania.

[3] Bowen, M., Morara, M. \& Mureith. (2009). Management of Business Challenges among Small and Micro enterprises in Nairobi-Kenya. KCA Journal of Business and Management, 2 (1). 
[4] Kipesha, E. F \& Zhang, X. (2013). Sustainability, Profitability and Outreach Tradeoffs. Evidences from Microfinance Institutions in East Africa. European Journal of Business and Management. 5. 136-148.

[5] Marwa, N. \& Aziakpono, M. (2015). Financial Sustainability of Tanzanian Saving and Credit Cooperatives. Economic Research Southern Africa (ERSA) Working Paper 529.

[6] Nyamsogoro, G. D, (2010). Financial Sustainability of Rural Microfinance in Tanzania. $\mathrm{PhD}$ Thesis, University of Greenwich, UK.

[7] Filene, (2011), "Credit Union Financial Sustainability: A Colloquium at Harvard University", Filene Research Institute Report Number 231.

[8] Hubbard, G. (2009). Measuring organizational performance: beyond the triple bottom line. Business strategy and the environment, 18 (3), 177-191.

[9] Doicui, M. (2009). The Microfinance Operations Sustainability's triple bottom line Characteristics in Eastern Europe. A case study on the Romanian Microfinance Sector.

[10] Thela, T. (2012). The efficiency and sustainability of Microfinance Institutions in South- Africa Masters Dissertation, University of Johannesburg.

[11] Glautier, M. W. E. \& Underdown, B. (2001). Accounting theory and Practice, 7th Edition. United Kingdom: FT Prentice-Hall.

[12] Marriott, R. Edwards, J. R. \& Mellett, H. J. (2004). Introduction to Accounting, 3rd Edition. London: Sage Publication Limited.

[13] Charoenrat, T. (2012). The Technical Efficiency of Thai Manufacturing Small and Medium Enterprises: A Comparison between pre- and post-financial of 1997. PhD Thesis, University of Wollongong.

[14] Coelli, T. J., Rao, D. S. P., O'Donnell, C. J.\& Battese, G. E. (2005). An Introduction to Efficiency and Productivity Analysis 2. Springer, New York, USA.

[15] Debru, G. (1951). The Coefficient of Resource Utilisation. $\begin{array}{llll}\text { Econometrica, } & 19 & \text { (3), 273-292. }\end{array}$ http://dx.doi.org/10.2307/1906814.

[16] Farrell, M. J. (1957). The Measurement of Productive Efficiency. Journal of the Royal Statistical Society, 120 (3), 253-290.

[17] Koopmans, T. C. (1951). An Analysis of Production as Efficient Combination of Activities. In T. C. Koopmans (ed.) Activity Analysis of Production and Allocation. New York: Cowles Commission for Research in Economics. (Monograph No. 13.)

[18] Kumbhakar, S. C. and Lovell, C. K. (2000). Stochastic production frontier. Cambridge: Cambridge University Press.

[19] Ngeh, E. T. (2014). Technical Efficiency and Manufacturing Export Performance in Cameroon. PhD Dissertation, University of Dar-es-Salaam, Tanzania.
[20] Njiku, A. R. \& Nyamsogoro, G. D, (2018). Determinants of Technical Efficiency for Small Scale Sunflower oil processing firms in Tanzania: One stage Stochastic Frontier Approach. Asian Journal of Economics and Empirical Research, 5 (1), 79-86.

[21] Lévesque, M. \& Minniti, M. (2006). The effect of aging on entrepreneurial behavior. Journal of Business Venturing, 21, 177-194.

[22] Admassie, A. \& Matambalya, F. (2002). Technical Efficiency of Small and Medium Enterprises: Evidence from a Survey of Enterprises in Tanzania, Eastern Africa Social Science Research Review, 18 (2), 1-29.

[23] Belenzon, S. \& Zarutskie, R. (2013). Consuming the Firm: Owner Age, Exit Strategy, and Firm Performance, Federal Reserve Board, Division of Research and Statistics, Washington, DC.

[24] Borga, F., Citterio, A., Noci, G., \& Pizzurno, E. (2009). Sustainability Report in Small Enterprises: Case studies in Italian furniture companies. Business Strategy and the Environment, 18 (3), 162-176.

[25] Barney, J. (1991). Firm resources and sustained competitive advantage. Journal of Management, 1, 99-120.

[26] Field, A. (2009). Discovering statistics using SPSS. Sage Publications

[27] Ahmed, M. S \& Ahmed, M. D. (2013). Efficiency Variation of Manufacturing Firms: A Case Study of Seafood Processing Firms in Bangladesh. Review of Economics \& Finance. Academic Research Centre of Canada.

[28] Le, V. \& Harvie, C. (2010). Firm Performance in Vietnam: Evidence from manufacturing SME, University of Wollongong Economics working paper series 2010.

[29] Niringiye, A., Luvanda E., \& Shitundu J. (2010). Firm Size and Technical Efficiency in East African Manufacturing Firms Current Research Journal of Economic Theory, 2 (2), 69-75.

[30] Charoenrat, T., Harvie, C. \& Amornkitvikai, Y. (2013). Thai Manufacturing Small and Medium Sized Enterprise Technical Efficiency: Evidence from firm-level industrial census data. Journal of Asian Economics, 27, 42-56.

[31] Radam, A., Abu, M. \& Abdullah, A. M. (2008). Technical Efficiency of SMEs in Malaysia: A Stochastic Frontier Production Model. Journal of Economics and Management, 2 (2), 395-408.

[32] Msuya, E., \& Ashimogo, G. (2005). Estimation of Technical Efficiency in Tanzanian Sugarcane Production: A case study of Mtibwa Sugar Estate Out growers Scheme. Online at http://mpra.ub.uni-muenchen.de/3747. July 15th, 2014.

[33] Gujarati, D. (2003). Basic Econometric. USA International edn, McGraw-Hill 4th edition. 